Crop Breeding and Applied Biotechnology 15: 106-111, 2015

Brazilian Society of Plant Breeding. Printed in Brazil

NOTE

http://dx.doi.org/10.1590/1984-70332015v15n2n19

\title{
Chromosome doubling in Paspalum notatum var. saure (cultivar Pensacola)
}

\author{
Roberto Luis Weiler ${ }^{1}$, Karine Cristina Krycki², Divanilde Guerra ${ }^{3}$, Carine Simioni $^{*}$ and Miguel Dall'Agnol ${ }^{2}$ \\ Received 18 February 2014
}

Accepted 12 November 2014

\begin{abstract}
Paspalum notatum is one of the most important native grassland species of southern Brazil, and the main forage source for livestock. The native ecotypes are tetraploid and have apomictic reproduction, which prevents the registration and protection of plant varieties. However, the cultivated variety Paspalum notatum var. saurae (cultivar Pensacola) is diploid and sexual. The objective of this study was to artificially produce polyploid cv. Pensacola plants, to be used as female parents in crosses with male tetraploid and apomictic parents. Seedlings and seeds were immersed in colchicine solutions for different periods. A tetraploid chromosome number was confirmed in three plants. The reproduction mode of the resulting polyploid plants will be assessed; if confirmed to be sexual, they can be used in crosses with native apomictic plants to breed new intraspecific hybrids.
\end{abstract}

Key words: Polyploidy, chromosome duplication, Paspalum notatum.

\section{INTRODUCTION}

The grasslands Campos Sulinos are natural ecosystems with high biodiversity and have been the main forage source of livestock. In recent decades, however, the original cover with grasslands of more than half of the Campos surface in the state of Rio Grande do Sul was substituted by other vegetation types, without a proper evaluation of the forage potential. Animal husbandry has been replaced by other seemingly more profitable activities in the short term. The conservation of the grasslands is being threatened by the ongoing conversion to annual crops and to forestry and by degradation, along with the invasion of alien species and inappropriate use (Behling et al. 2009).

Among the various native species, Paspalum notatum Flügge (bahiagrass) stands out as forage, which is one of the most important native pasture species of southern Brazil, Uruguay, northeastern Argentina, and southern Paraguay (Quarin et al. 1984). This grass is the main herbal product of most grasslands of Rio Grande do Sul (Nabinger and Dall'Agnol 2008), and tends to expand gradually for being resistant to trampling and growth stimulation by grazing (Pozzobon and Valls 1997).
In the genus Paspalum, the ploidy level and reproduction mode are closely correlated; diploidy is correlated with sexual reproduction and alogamy and polyploidy is correlated with apomixis (Adamowski et al. 2005). Most biotypes of $P$. notatum are autotetraploids $(2 \mathrm{n}=4 \mathrm{X}=40)$ and are reproduced by aposporious apomixis (pseudogamy) (Forbes and Burton 1961). Most apomictic tetraploid species have, however, sexual conspecific, diploid and self-incompatible partners (Quarin and Norrmann 1990). The diploid $(2 \mathrm{n}=2 \mathrm{x}=20$ ) variety Pensacola grass (Paspalum notatum var. Saurae), native to northeast and west-central Argentina, was described. The diploid form reproduces sexually by regular meiosis and is alogamous in view of its self-incompatibility system (Burton 1946, Forbes and Burton 1961). This cultivar is widely exploited in the southern region of the country, due to characteristics such as: tolerance to intensive and frequent trampling, short plant height, no harmful plant structures and no known antinutritional properties (Haddad et al. 1999). In Rio Grande do Sul, bahiagrass is particularly important, mainly in the Planalto region, which calls for comparisons with native ecotypes in terms of forage production and value (Dall'Agnol et al. 2006).

\footnotetext{
${ }^{1}$ Instituto Rio Grandense do Arroz (IRGA), Estação Experimental do Arroz, Avenida Bonifácio Carvalho Bernardes, 1494, 94.930-030, Cachoeirinha, RS, Brazil

${ }^{2}$ Universidade Federal do Rio Grande do Sul (UFRGS), Departamento de Plantas

Forrageiras e Agrometeorologia, Avenida Bento Gonçalves, 7712, 91.501-970, Porto Alegre, RS, Brazil. *E-mail: carine.simioni@ufrgs.br

${ }^{3}$ Universidade Estadual do Rio Grande do Sul (UERGS), Unidade em Três Passos, Faculdade de Agronomia, Rua Cipriano Barata, 47, 98.600-000, Três Passos, RS, Brazil
} 
The different ploidy levels between sexual (diploid) and apomictic (tetraploid) genotypes are a major limitation for the production of hybrid plants in breeding programs (Carneiro and Dusi 2002). The artificial induction of polyploidy, promoting chromosome duplication in diploid sexual plants of natural bahiagrass populations and the subsequent use of duplicate genotypes in intraspecific mating systems, opens new possibilities for breeding programs.

The objective of this study was to induce polyploidy in seeds and seedlings of Paspalum notatum var. saurae (cultivar Pensacola) to generate tetraploid plants with sexual reproduction and to use them in intraspecific mating schemes, using apomictic germplasm native to Rio Grande do Sul as male parent to produce fertile hybrids with a broader genetic basis, in order to generate genotypes with agronomic potential that can be registered and licensed by the Ministry of Agriculture, Livestock and Supply of Brazil (MAPA).

\section{MATERIAL AND METHODS}

This study was performed at the Laboratory of Cytogenetics, Department of Forage Plants and Agrometeorology, Faculty of Agronomy, of the Federal University of Rio Grande do Sul.

The plant material was taken from a commercial seed lot of Paspalum notatum var. saurae (cultivar Pensacola), diploid $(2 \mathrm{n}=2 \mathrm{x}=20)$, with sexual reproduction. Pensacola is the only cultivar of the species with seeds available on the market. For chromosome duplication in seedlings, the seeds were deglumed and germinated on sterile petri dishes. Immediately after cotyledon opening and apical bud appearance of the germinating seeds, they were immersed in a colchicine solution $(0.01,0.05,0.08,0.10$, and $0.20 \%$ of $\{(\mathrm{S})$-N- $(5,6,7,9$-Tetrahydro-1,2,3,10-tetramethoxy9-oxobenzo [a] heptalen-7-yl $\}$ ), for 2, 3, 4, 5, 6, 18 and 24 $\mathrm{h}$. After application of the drug, the seedlings were washed thoroughly with running water, planted in pots and the morphological changes and mortality rate were recorded during their development. For induction of chromosome duplication in seeds, 1000 seeds were treated, of which 500 were soaked in $0.10 \%$ and the other 500 in a $0.15 \%$ colchicine solution, both for a period of $24 \mathrm{~h}$.

The effectiveness of chromosomal duplication was checked by measuring the DNA amount with a ploidy analyzer and by chromosome counting techniques in somatic cells of root tips (mitosis) and mother cells of pollen grains (meiotic analysis).

Measurements of DNA quantity were performed at the Laboratory of Plant Biotechnology Embrapa Beef Cattle,
Campo Grande, MS, using a Partec ploidy analyzer. For this purpose, samples of about $0.5 \mathrm{~cm}^{2}$ of one leaf per plant were ground in $200 \mu \mathrm{l}$ of extraction buffer (CyStain UV Solution A - Partec, Münster, Germany).Thereafter, the nuclei were stained with the dye solution in an extraction volume of $400 \mu \mathrm{l}$ (UV CyStain Solution B - Partec, Münster, Germany). The equipment compares an example with a known ploidy level with the sample in which the ploidy level is to be determined. The results are presented in graphs, showing the DNA amount contained in the cell nucleus. Plants with DNA patterns consistent with the tetraploid ploidy level were subjected to cytogenetic analysis (chromosome counting in root tip or mother cells of pollen grains) to prove chromosome duplication.

The analyses of the ploidy level by chromosome counting in somatic cells (mitosis) were performed in root tip cells from pretreated adult plants, maintained for $20 \mathrm{~h}$ in a saturated paradichlorobenzene solution, at $4{ }^{\circ} \mathrm{C}$. After this period, the root tips were fixed in a 3:1 solution (ethanol: acetic acid) for $24 \mathrm{~h}$ and then stored in $70 \%$ ethanol in a refrigerator until analysis. At the time of analysis, the tips were hydrolyzed in $1 \mathrm{~N} \mathrm{HCl}$ (normal hydrochloric acid) for 10 min at $60{ }^{\circ} \mathrm{C}$, followed by Feulgen staining technique plus $1 \%$ propionic carmine, and examined under an optical microscope.

To verify the effectiveness of chromosome duplication in the meiotic analyses, young inflorescences, surrounded by the flag leaf, in the early development stages, were collected. These were fixed in an absolute ethanol solution: acetic acid (3: 1) for $24 \mathrm{~h}$, transferred to $70 \%$ ethanol and stored under refrigeration (Araújo et al. 2005). For the analyses, the microsporocytes were crushed and stained with $1 \%$ propionic carmine. Counts were performed in the associations in diakinesis and metaphase I, mainly because these stages have an easily visualizable chromosome pairing configuration. In both cytogenetic analysis (mitotic and meiotic analysis), as indicated in the literature, a minimum of 20 cells per plant was checked by chromosome number counting (Pozzobon and Valls 1997, Simioni et al. 2006, Dahmer et al. 2008).

\section{RESULTS AND DISCUSSION}

A total of 1761 seedlings and/or seeds were subjected to the different colchicine treatments. Of the 713 plants surviving the treatment, 370 reached adulthood and 352 were analyzed for effectiveness of the treatment (Table 1).

The chromosome number in mitotic cells of 53 plants (root tip cells) and in meiotic cells of 58 plants (mother cells of pollen grains) was counted under a light microscope. 
RL Weiler et al.

Table 1. Summary of results obtained by polyploidy induction: colchicine concentrations, time of exposure to the drug, number of surviving plants, plants grown in pots, plants evaluated

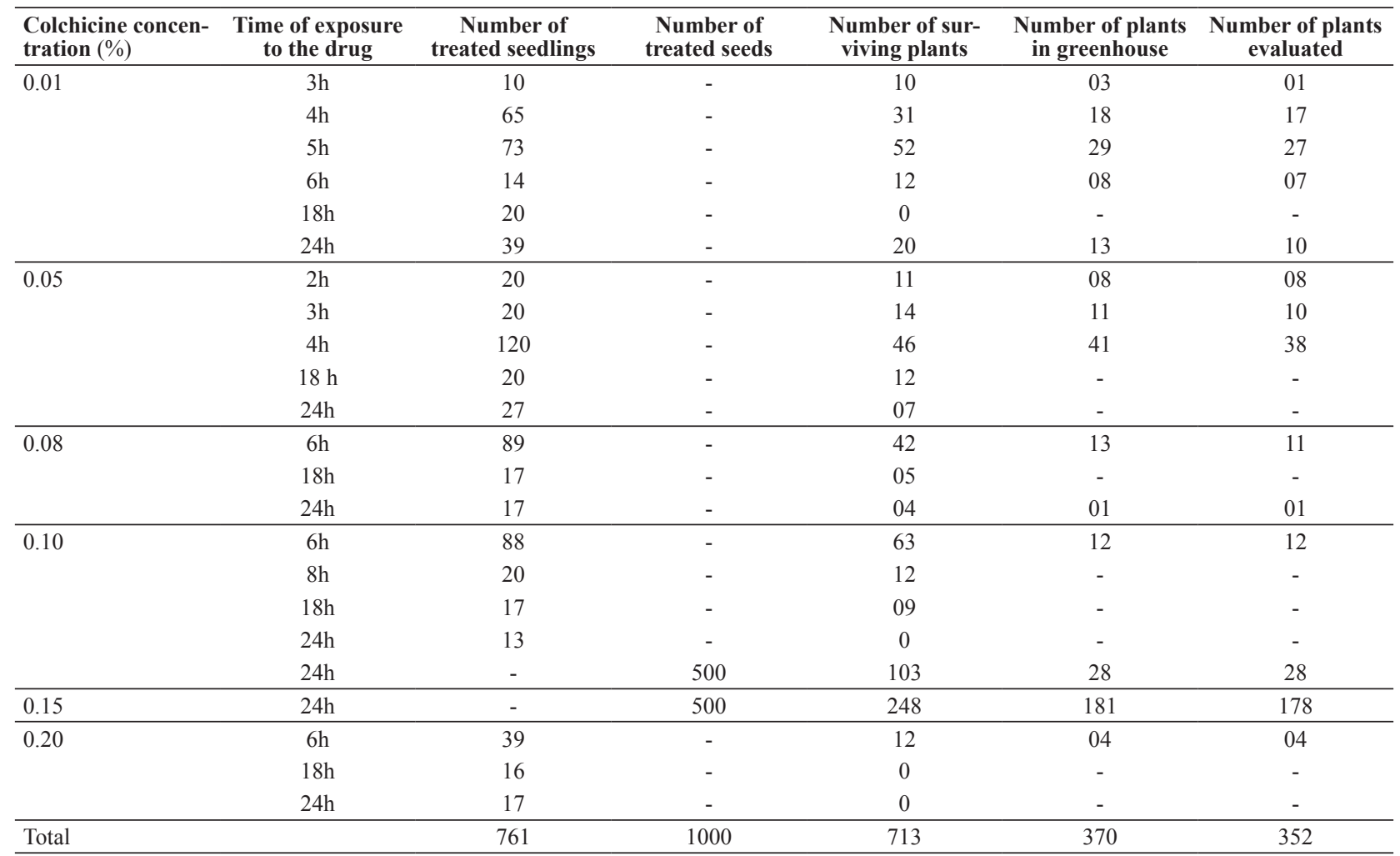

Cytogenetic analyses are very time-and labor-demanding, so analyses in ploidy analyzer were required to accelerate the process of checking the effectiveness of chromosome duplication. The difficulty is increased by the small chromosome size and low cell division rate, commonly observed in C4 grasses, including bahiagrass (Quesenberry et al. 2010). In the ploidy analyzer, 241 plants were evaluated, of which 12 contained DNA quantities corresponding to the tetraploid ploidy level. However, cytogenetic analysis confirmed chromosome duplication in only two of these plants.

Acuña et al. (2007) used a ploidy analyzer to confirm the chromosome number in 20 plants selected for plant vigor from among 300 plants in the field, in which chromosome duplication had been artificially induced in vitro by Quesenberry and Smith (2003). The population was first planted in the field for a visual assessment of plant vigor, to select the most vigorous for analysis of the ploidy level. Chromosome duplication was confirmed in all 20 selected plants.

Reyno et al. (2012) analyzed the ploidy level of Paspalum notatum by flow cytometry. In the analysis in which the DNA content peaks differed from expectations, the chromosome number in mitosis was counted in root tip cells; in this case, at least three cells of three different roots per plant were analyzed.

As a result of this experiment, a tetraploid chromosome number was confirmed in three plants, which were designated: 'WKS 3' (seedling treatment at $0.08 \%$ for $6 \mathrm{~h}$ ), analyzed in meiotic cells; 'WKS 63' (seed treatment in $0.10 \%$ for $24 \mathrm{~h}$ ), checked with a ploidy analyzer and confirmed in meiotic cells and 'WKS 92 (seed treatment in $0.15 \%$ for $24 \mathrm{~h}$ ) also checked with ploidy analyzer and confirmed in meiotic cells (Figure 1). The seed treatment was more effective in producing polyploid plants than the seedling treatments. It was observed that in the seedlings treated with high colchicine concentrations $(0.10 \%$ or higher), and/or for a longer exposure period ( 18 to $24 \mathrm{~h}$ ) the death rate was $100 \%$. In four plants of this experiment, it was not possible to distinguish the ploidy level due to the emergence of chimeric roots. The occurrence of chimeras and consequently the emergence of mixaploid plants is common, since the chromosome number can only be doubled in cells that are mitotically active during the treatment. The affected tissue is disorganized, resulting in irregularities in the chromosome number (Sybenga 1992), so some tissues or plants 
can have sectors with and sectors without chromosome doubling (Taylor and Quesenberry 1996).

Quarin et al. (2001) induced chromosome doubling in 24 diploid $P$. notatum seedlings, where tetraploidization was confirmed in only one plant while another had octaploid and tetraploid sectors. In the same study, P. notatum chromosomes were duplicated by colchicine application directly in the culture medium of plantlets. The authors reported effective chromosome doubling in two plants treated with $0.2 \mathrm{~g} \mathrm{~L}^{-1}$ of the drug. The same authors artificially induced calli of young inflorescence tissue with colchicine. The calli were subjected to flow cytometry analyses for confirmation of chromosome duplication, and only the callus region with chromosome doubling was used for plant regeneration. Of 40 inflorescences, 37 regenerated calli; of these, $74 \%$ had tetraploid regions and the most efficient colchicine dose was $0.2 \mathrm{~g} \mathrm{~L}^{-1}$ for $72 \mathrm{~h}$.

Quesenberry et al. (2010) induced chromosome duplication in calluses of $P$. notatum, using the antimitotic agents colchicine, orysalin and trifluralin. The effectiveness of polyploidization was confirmed in three analyses: based on the stomata size, determination of the chromosome number in mitotic root tip cells and flow cytometry analysis. The trifluralin and colchicine treatments were the most effective. The authors mentioned that the evaluation based on stomata size can be used for an initial screening when there are many treated plants to analyze. However, a discrepancy of $12 \%$ was found between stomata-size and flow cytometry analyses. The authors also report difficulties in meiotic analysis of root tips, and difficulties in chromosome separation and counting, requiring a long time for this analysis. Similar difficulties appeared in this study, where in the majority of cells in diakinesis, the chromosomes were not clearly distributed, making counting difficult.

Simioni and Valle (2009) used in vitro culture to induce polyploidy in diploid accessions with sexual reproduction of Brachiaria decumbens. The shoots regenerated from explants were isolated and placed in a culture medium supplemented with a colchicine concentration of $0.01 \%$ for $48 \mathrm{~h}$. A total of 216 adult plants were regenerated and 128 were analyzed cytogenetically. The chromosome number of five of these was effectively duplicated and the sexual reproduction mode confirmed by cytoembryological analysis in clarified ovaries.

Chromosome duplication was induced in diploid seedlings of Lolium multiflorum, which were immersed in different colchicine solutions for an exposure time of $3 \mathrm{~h}$ and 24h. Determination of DNA content of plants obtained from seedlings subjected to chromosome duplication was

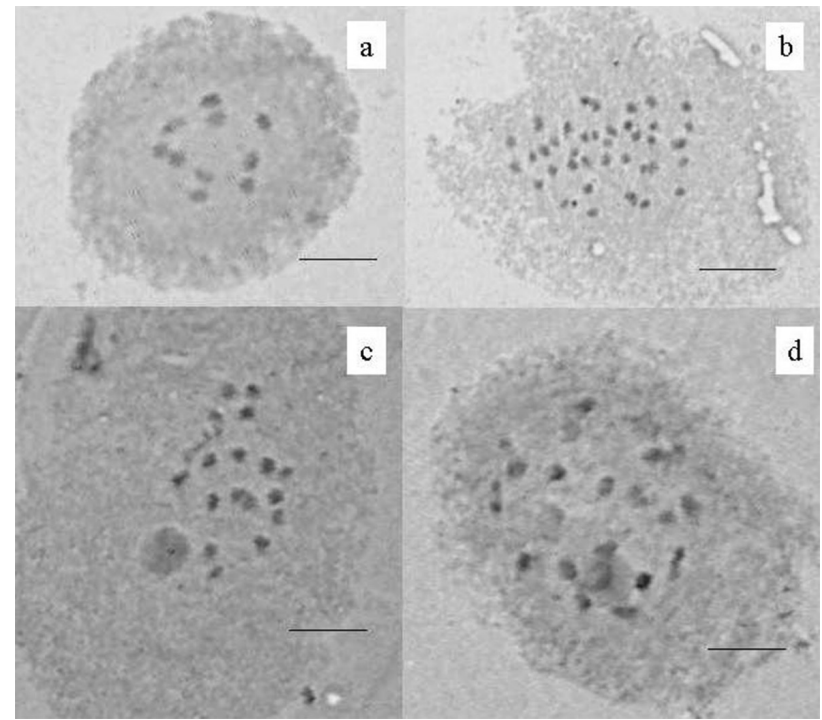

Figure 1. Aspects of meiosis (chromosome settings) proving chromosome duplication. (a) Control: P. notatum cv Pensacola: 20 chromosomes (10 bivalent in diakinesis); (b) plant 'WKS 63': 40 univalent in early anaphase I; (c) plant 'WKS 92: 40 chromosomes (20 bivalent in diakinesis); (d) plant 'WKS 3': 40 chromosomes (20 bivalent in diakinesis). Bar $10 \mu \mathrm{m}$.

performed by the flow cytometry technique and was also verified by means of chromosome counts. The percentage of polyploids obtained was $20 \%$. The polyploiding effect of colchicine was obtained with $24 \mathrm{~h}$ exposure (Pereira et al. 2014).

The colchicine treatment was effective, even at a low percentage, as polyploid plants could be obtained using this technique. It is noteworthy that two plants with induced polyploidy were obtained by the direct seed treatment, a new technique for Paspalum notatum, so far not described in the literature. The analyses in mitotic and/or meiotic cells are more reliable than analysis with ploidy analyzer, for which the requirements in terms of reagents and trained staff are greater.

The seed treatment can be performed at a larger scale and thus increase the chances of success, but the more plants are treated, the greater will be the labor demand to analyze the effectiveness of polyploidization. The dose and duration of exposure to colchicine may be higher in the seed treatment, since in this study, doses of 0.10 and $0.15 \%$ for $24 \mathrm{~h}$ were effective to obtain results in seeds, while seedlings were influenced by a treatment with $0.08 \%$ for $6 \mathrm{~h}$.

Although chromosome doubling occurred in only $0.85 \%$ of the evaluated plants in this study, the three polyploidized plants represent a breakthrough in this breeding program, opening new perspectives of mating strategies in this species, increasing the genetic variability and allowing the 
registration of new varieties.

The chromosome-doubled plants are cultivated in a greenhouse and their reproduction mode is being evaluated to confirm that they are sexual. In later stages, they are cytogenetically evaluated to see if the viability/fertility (regular meiosis and pollen viability) is maintained, to confirm them as female parents for future crosses, to breed intraspecific hybrids of this important grass species.

\section{ACKNOWLEDGEMENTS}

We appreciate the financial support of SULPASTO, CNPq and CAPES. We are indebted to IBONE (Instituto de Botânica del Nordeste da Argentina/Institute of Botany del Northeast of Argentina), in particular the researchers Camilo Luiz Quarín and Carlos Acunã. We thankfully acknowledge the assistance of EMBRAPA Beef Cattle - Campo Grande (MS), in particular the researcher Cacilda Borges do Valle.

\section{Duplicação cromossômica em Paspalum notatum var. saure (cultivar Pensacola)}

Resumo - Paspalum notatum é uma das mais importantes espécies das pastagens nativas do Sul do Brasil, que é a principal fonte forrageira para a pecuária. Os ecótipos nativos são tetraploides e de reprodução apomítica, o que impede o registro e a proteção de cultivares. Porém, uma variedade cultivada, Paspalum notatum var. saurae (cultivar Pensacola) é diplóide e sexual. O objetivo deste trabalho foi de poliploidizar artificialmente plantas de cv Pensacola, para serem utilizadas como genitores femininos em cruzamentos com genitores masculinos tetraploides e apomíticos. Plântulas e sementes foram tratadas por imersão com soluções de colchicina por tempo de exposição variável. Três plantas confirmaram número cromossômico tetraploide. As plantas polyploides obtidas serão avaliadas quanto ao modo de reprodução; se confirmarem ser sexuais, serão utilizadas nos esquemas de cruzamentos com plantas apomiticas nativas para obtenção de novos híbridos intraespecíficos.

Palavras-chave: Poliploidia, duplicação cromossômica, Paspalum notatum.

\section{REFERENCES}

Acuña CA, Blount AR, Quesenberry KH, Hanna WW and Kenworthy KE (2007) Reproductive characterization of bahiagrass germplasm. Crop Science 47: 1711-1717.

Adamowski EV, Pagliarini MS, Mendes-Bonato AB, Batista LAR and Valls JFM (2005) Chromosome numbers and meiotic behavior of some Paspalum accessions. Genetic and Molecular Biology 28: 773-780.

Araújo ACG, Nóbrega JM, Pozzobon MT and Carneiro VT C (2005) Evidence of sexuality in induced tetraploids of Brachiaria brizantha (Poaceae). Euphytica 144: 39-50.

Behling H, Jeske-Pieruschka V, Schuler L and Pillar VP (2009) Dinâmica dos campos no sul do Brasil durante o Quaternário Tardio. In Pillar VP, Muller SC, Castilhos ZMS and Jacques AVA (Eds) Campos Sulinos - conservação e uso sustentável da biodiversidade. Editora Ministério do Meio Ambiente, Brasília, p. 13-25.

Burton GW (1946) Bahiagrass types. Journal of American Society of Agronomy 38: 273-281.

Carneiro VTC and Dusi DMA (2002) Apomixia. Biotecnologia, Ciência e Desenvolvimento 25: 36-42.

Dall'Agnol M, Steiner MG, Barea K and Scheffer-Basso SM (2006) Perspectivas de lançamento de cultivares de espécies forrageiras nativas: o gênero Paspalum. In Dall'Agnol M, Nabinger C and Santos RJ (Eds) Anais do $1^{\circ}$ Simpósio de Forrageiras e Produção Animal, UFRGS, Porto Alegre, p. 147-160.

Dahmer N, Schifino-Wittmann MT, Dall'Agnol M and Castro B (2008) Cytogenetic data for Paspalum notatum Flügge accessions. Scientia Agricola 65: 381-388.

Forbes I and Burton GW (1961) Induction of tetraploid and rapid field method of detecting induced tetraploidy in Pensacola bahiagrass.
Crop Science 1: 383-384.

Haddad CM, Domingues JL, Castro FGF and Tamassia LFM (1999) Características de produção e valor nutritivo do capim Pensacola (Paspalum notatum Flügge var. saurae Parodi) em função da idade de corte. Scientia Agrícola 56: 753-761.

Nabinger C and Dall'Agnol M (2008) Principais gramíneas nativas do RS: características gerais, distribuição e potencial forrageiro. In Dall'Agnol M; Nabinger C and Santos RJ (Eds) Anais do $3^{\circ}$ simpósio de forrageiras e produção animal. UFRGS, Porto Alegre, p.7-54.

Pereira RC, Ferreira MTM, Davide LC, Pasqual M, Mittelmann A and Techio VH (2014) Chromosome duplication in Lolium multiflorum Lam. Crop Breeding and Applied Biotechnology 14: 251-255.

Pozzobon MT and Valls JM (1997) Chromosome number in germplasm accessions of Paspalum notatum (Gramineae). Brazilian Journal Genetics 20: 29-34.

Quarin CL, Burson BL and Burton GW (1984) Cytology of intra- and interspecific hybrids between two cytotypes of Paspalum notatum and P. cromyorrhizon. Botanical Gazette 145: 420-426.

Quarin CL, Espinoza F, Marinez EJ, Pessino SC and Bovo OA (2001) A rise of ploidy level induces the expression of apomixis in Paspalum notatum. Sexual Plant Reproduction 13: 243-249.

Quarin CL and Normann GA (1990) Interspecifc hibryds between five Paspalum species. Botanical Gazette 151: 366-369.

Quesenberry KH, Dampier JM, Lee YY, Smith RL and Acuña CA (2010) Doubling the chromosome number of bahiagrass via tissue culture. Euphytica 175: 43-50.

Quesenberry KH and Smith RL (2003) Production of sexual tetraploid bahiagrass using in vitro chromosome doubling agents. In Hopkins A and Barker R (Eds) Proceedings of the 3rd international 
symposium, molecular breeding of forage and turf. Noble Foundation, Dallas, p. 145.

Reyno R, Narancio R, Speranza P, Do Canto J, Lopez-Carro B, Hernandez P, Burgueno J, Real D and Rizza MD (2012) Molecular and cytogenetic characterization of a collection of bahiagrass (Paspalum notatum Flügge) native to Uruguay. Genetic research and Crop Evolution 59: 1823-1832.

Simioni CS and Valle CB (2009) Chromosome duplication in Brachiaria (A. Rich.) Stapf allows intraspecific crosses. Crop Breeding and
Applied Biotechnology 9: 328-334.

Simioni C, Schifino-Wittmann MT and Dall'Agnol M (2006) Sexual polyploidization in red clover. Scientia Agricola 63: 26-31.

Sybenga J (1992) Manipulation of genome composition. B. Gene dose: duplication, polyploidy and gametic chromosome number. In Springer-Verlag (Ed) Cytogenetics and plant breeding. SpringerVerlag, Berlin, p. 327-371.

Taylor NL and Quesenberry KH (1996) Red clover science. Kluwer Academic, Dordrecht, 226p. 